\title{
POTRET MASALAH PERBURUHAN DI INDONESIA PASCA REFORMASI TAHUN 1998
}

\author{
Oleh : \\ - Argo Pambudi \\ FIS UNY
}

\section{Abstrak}

Masih tingginya angka pengangguran korban PHK, banyaknya aksi unjuk rasa kaum buruh dan munculnya berbagai bentuk pergolakan buruh di Indonesia pasca reformasi tahun 1998 mengindikasikan belum terselesaikannya persoalan-persoalan perburuhan di In-donesia secara tuntas. Ada 2 kelompok penyebab masih terus exist-nya masalah perburuhan itu di Indonesia. Pertama adalah faktor peningkatan kuantitas tenaga kerja yang terus-menerus tanpa diimbangi peningkatan daya serap lapangan kerja yang cukup. Kedua, tidak mampunya institusi pemerintah, melalui kebijakan yang dikeluarkannya menangani permasalahan yang terus berkembang tersebut. Tulisan ini mencoba memaparkan potret masalah perburuhan di Indonesia yang masih mengemuka pada beberapa dekade terakhir, khususnya pada masa pasca reformasi politik di Indonesia tahun 1998

Kata kunci : reformasi, kebijakan perburuhan

\section{Pendahuluan}

Eksistensi masalah perburuhan, di Indonesia pada khususnya, selalu bersumber pada konflik kepentingan antara buruh dengan pengusaha dalam konteks hubungan Industrial. Antara kaum buruh dengan pengusaha senantiasa terdapat hubungan yang dilandasi dua kepentingan yang berseberangan. Disatu pihak, buruh memiliki kepentingan mengoptimalkan perolehan pendapatannya dalam bentuk gaji, upah, dan berbagai tunjangan dari perusahaan. Sebaliknya, kaum pengusaha memiliki ke- pentingan meningkatkan efisiensi dan kemampuan kompetensi perusahaannya. Buruh memandang konsep upah, gaji dan semacamnya itu sebagai pendapatan untuk memenuhi kebutuhan hidup diri dan keluarganya. Harapan dan motivasi untuk mendapatkan upah dari perusahaan merupakan dorongan utama kaum buruh untuk tetap menjalin hubungan kerja dengan perusahaan. Bagi kaum buruh, semakin tinggi tarif upah, gaji dan tunjangan-tunjangan lainnya dipandangnya semakin baik. Sebaliknya, kaum pengusaha memandang 
tenaga buruh merupakan komponen utama proses produksi di perusahaan. Sebagai kompensasinya, gaji, upah dan berbagai tunjangan lainnya bagi buruh harus dibayar sebagai biaya produksi (cost). Artinya, tarif upah buruh yang tinggi dipandang menyebabkan inefficiency proses produksi. Upah buruh yang rendah dipandang akan meningkatkan efisiensi dan daya saing perusahaan. Jadi tarif upah rendah inilah yang senantiasa dicita-citakan kaum pengusaha.

Dua kepentingan yang berseberangan inilah yang senantiasa melatar-belakangi mereka untuk tetap menjalin hubungan satu sama lainnya. Namun, dua kepentingan yang berseberangan ini sekaligus dapat menjadi akar munculnya berbagai masalah perburuhan, yaitu manakala hubungan mereka tidak harmonis lagi. Titik keseimbangan atau kehamonisan antara dua kepentingan tersebut tidak tercapai namun hubungan mereka tetap harus berlangsung. Pada kondisi seperti itulah perselisihan antara buruh dengan pengusaha terus terjadi. Sangat jarang personalan perburuhan muncul disebabkan oleh karena faktor lain diluar itu. Masalah perburuhan yang disebabkan oleh karena perselisihan antara buruh dengan buruh ataupun antara buruh dengan pemerintah sangat jarang terjadi. Kalaupun ada perselisihan antara buruh dengan pemerintah, akar permasalahannya selalu bersumber pada hubungan antara buruh dengan pengusaha yang diintervensi kebijakan pemerintah yang tidak netral atau dipandang memihak pada salah satu kepentingan saja. Bisa terjadi kebijakan pemerintah dirasakan tidak adil dimata kaum buruh, karena buruh merasa kepentingannya tidak dilindungi. Sebaliknya bisa pula terjadi kebijakan pemerintah dirasakan tidak adil oleh kaum pengusaha, karena kebijakan pemerintah tersebut dipandang overprotective terhadap kaum buruh. Kaum pengusaha merasa terlampau berat diberi beban kewajiban oleh pemerintah demi melindungi kaum buruh yang pada umumnya "lebih miskin". Atau mungkin konflik bisa terjadi manakala pemerintah "terlampau netral", seolah lari dari permasalahan atau tidak menjalankan fungsinya sebagai penjaga keharmonisan hubungan tersebut. Pada kondisi seperti ini bentuk konflik akan bergeser dari konflik buruh melawan pengusaha menjadi konflik buruh melawan pemerintah ataupun pengusaha melawan pemerintah.

\section{Substansi Masalah Peburuhan di Indonesia}

Substansi masalah perburuhan pada hakekatnya berbentuk ketidak-adilan yang dialami tenaga kerja buruh dan/atau pengusaha dalam konteks hubungan industrial yang mereka lakukan. Pada banyak hal 
hubungan industrial ini sering diintervensi oleh pemerintah melalui kebijakan-kebijakan yang dikeluarkannya. Intervensi yang "berlebihan" cenderung mendistorsi thubungan tersebut sehingga justru menimbulkan berbagai persoalan yang rumit. Di Indonesia, peningkatan kualitas masalah perburuhan ini terbentuk sebagai akumulasi dampak intervensi tersebut. Berbagai kebijakan pembangunan ekonomi terdahulu kebanyakan tidak antisipatif terhadap munculnya berbagai masalah perburuhan ini. Di Indonesia sedikit sekali - kalau tidak boleh dikatakan tidak ada - kebijakan perburuhan/ketenagakerjaan pada khususnya, dan kebijakan pembangunan pada umumnya, yang memikirkan skenario jangka panjang untuk mencegah munculnya masalah ini. Diadopsinya nilai-nilai sistem ekonomi liberal dalam berbagai kebijakan pembangunan di Indonesia semenjak tahun 1967 membuat masalah perburuhan semakin jelas menampakkan dirinya di Indonesia. Kebijakan pembangunan tersebut tidak meng-utamakan penciptaan lapangan keja massal sebagai prioritas utamanya, namun lebih mengutamakan peningkatan pertumbuhan ekonomi makro semata. Pemerintahan Soeharto yang berkuasa lebih dari 30 tahun (1967 1998) kiranya tidak mau belajar dari sejarah kelam penerapan nilai-nilai sistem ekonomi liberal ini di negara- negara lain. Pengalaman praktek penerapan nilai-nilai liberal ini di berbagai negara pada masa lalu umumnya tidak memberikan kesejahteraan bagi seluruh individu, akan tetapi yang terjadi adalah : "sekelompok kecil kaum kapitalis melakukan eksploitasi ekonomi atas sebagian besar massa - yang kebanyakan berstatus sebagai buruh". Hal demikian inilah kiranya yang juga terjadi di Indonesia selama beberapa dekade terakhir mulai tahun 1967.

Kebijakan ekonomi-politik pemerintahan Soeharto dan penerusnya tidak memberikan prioritas yang tinggi pada usaha pencegahan munculnya berbagai masalah perburuhan ini untuk jangka panjang, namun justru cenderung memanfaatkannya sebagai sarana melanggengkan kekuasaannya. Kecenderungan ini sangat kentara pada masa pemerintahan Soeharto dimana peranan buruh secara terang-terangan dipinggirkan dalam proses pembuatan kebijakan bidang apapun, termasuk kebijakan yang menyangkut nasib buruh itu sendiri. Bilamana mendapat tentangan dari kaum buruh, pemerintah melalui alat kekuasaannya kerap bertindak represif terhadap gerakan buruh yang berkeinginan merubah nasibnya. Organisasi buruh disatukan agar mudah dikontrol pemerintah. Organisasi buruh diluar yang dijinkan pemerintah dianggap ilegal, sehingga pemerintah, dengan meng-atas- 
nama supremasi hukum, berhak melarang segala bentuk aktivitasmya.

Pasca reformasi politik keadaannya agak berubah, namun hanya untuk sementara saja. Penunjukkan Jacob Nuwa Wea - sebelumnya dikenal sebagai aktivis advokasi buruh dari Federasi Serikat Pekerja Seluruh Indonesia (FSPSI) - sebagai Menteri Tenaga Kerja pada masa pemerintahan Presiden Megawati Soekarnoputri telah memberi angin segar dan harapan baru bagi perjuangan kepentingan buruh di Indonesia. Penunjukkan Jacob Nuwa Wea ini sedikit banyak telah memberi angin segar kebebasan dan membuka akses kaum buruh untuk menyampaikan aspirasinya dalam forum pengambilan keputusan pemerintah yang menyangkut kepentingannya. Aksi unjuk rasa kaum buruh di berbagai tempat kini banyak ditolelir pemerintah. Aparat keamanan di lapangan tidak segarang masa pemerintahan Sceharto dulu. Beberapa kebijakan ketenagakerjaan dan pernyataan sementara pejabat mulai terasa ada yang berpihak pada kepentingan kaum buruh, seperti : (1) Keluarnya SK pencabutan puluhan SIUP PJTKI yang terbukti nakai; (2) Larangan sementara bagi 8 propinsi (Jawa Timur, Jawa Barat, Jawa Tengah, Kalimantan Barat, Kalimantan Timur, Nusa Tenggara Barat, Nusa Tenggara Timur dan Sulawesi Selatan) mengirimkan TKI-nya ke luar negeri menyusul dipulangkannya ratusan ribu TKI ilegal dari Malaysia pada tahun 2002 ; (3) Pemberlakuan kembali SK Menaker No. 150 Tahun 2000 tentang Penyelesaian PHK dan Penetapan Uang Pesangon, Uang Penghargaan Masa Kerja, dan Gand Kerugian di Perusahaan ' ; (4) Pemberlakuan Keputusan Gubernur DKI Jakarta No. 3052 Tahun 2001 tentang UMP DKI Jakarta Tahun 2002 yang telah dinyatakan ditunda oleh PTUN Jakarta" ; Pembatalan Keputusan P4P tentang penyelesai-an perselisihan perburuhan di PT Doson Indonesia, yang baru saja memPHK 6.822 orang buruh, oleh Menakertrans ; dan lain sebagainya. Kebijakan-kebijakan ketenagakejaan itu mengundang protes yang berkepanjangan dari kalangan pengusaha, baik PMDN maupun PMA - sesuatu yang tidak pemah terjadi di era pemerintahan sebelumnya. Namun demikian kebijakan-kebijakan yang banyak mengakomodasi kepentingan kaum buruh tersebut lebih banyak yang tidak dapat dimplementasikan di lapangan oleh karena berbagai faktor. Diantara faktor yang paling menentukan adalah begitu kuatnya dominasi kaum pengusaha dalam rangka menyediakan infrastruktur implementasi kebijakan perburuhan tersebut - disamping faktor-faktor lain seperti lemahnya penegakan hukum di Indonesia, lemahriya wibawa pemerintah dalam melakukan eksekusi sanksi yang te- 
lah dijatuhkan pengadilan, dan lain sebagainya. Akhimya kebijakan-kebijakan pemerintah tersebut tidak efektif dalam arti tidak berdampak pada peningkatan kesejahteraan kesejahteraan kaum buruh pada umumnya.

Selanjutnya upaya kaum buruh untuk dapat terus terlibat dalam pengambilan keputusan-keputusan ekonomi semakin suram oleh karena pemerintahan berikutnya tidak lagi menunjuk Jacob Nuwa Wea sebagai Menteri Tenaga Kerja lagi. Menteri Tenaga Kerja yang menggantikannya adalah Fanmi Idris. Seorang Fahmi Idris yang berlatar-belakang sebagai seorang politikus dan sekaligus seoang pengusaha tentu berbeda dengan Jacob Nuwa Wea dalam memandang setiap persoalan perburuhan. Keputusan untuk membentuk sebuah kebijakan ketenagakerjaan oleh seorang pengusaha sudah barang tentu akan selalu bias terhadap kepentingan kelompok pengusaha. Sulit rasanya Menteri Tenaga Kerja ini menjadi wasit yang benar-benar netral dalam menengahi konflik antara pengusaha dan buruh.

Gerakan buruh, sebagai manifestasi kekuatan tenaga kerja buruh terorganisir di Indonesia pasca reformasi politik tahun 1998 kiranya masih tetap menunjukkan pola lama, yaitu menuntut pemenuhan kebutuhan primer melalui kenaikan upah minimum, uang pesangon, tunjangan hari raya (THR), perbaikan fasilitas kerja dan tuntutan-tuntutan atas kompensasi kerja yang lain - termasuk di dalamnya tuntutan besaran uang pesangon bagi buruh yang menghadapi PHK dari perusahaan. Gerakan buruh ini menunjukkan bahwa pemenuhan kebutuhan dasar kaum buruh dewasa ini masih berada pada tingkat yang minimal. Lebih dari tiga dekade pembangunan dilaksanakan di lindonesia, ditambah dengan 7 tahun usia reformasi politik, tidak membawa dampak peningkatan kesejahteraan yang berarti bagi kaum buruh. Sangat sedikit tuntutan aksi buruh yang bernuasa dituar pola lania tersebut Kalaupun ada, hanya terbatas pada lingkungan perusahaan tertentu seperti BUMN ataupun kasus khusus yang kecil saja.

Berkaitan dengan maraknya gerakan buruh di Indonesia semenjak masa reformasi politik tahun 1998 kiranya bukan merupakan manifestasi munculnya kesadaran demokrasi kaum buruh di Indonesia, akan tetapi lebih merupakan reaksi kontektual kaum buruh menanggapi iklim kebebasan yang baru saja muncul di Indonesia. Perkembangan gerakan buruh itupun belum menjangkau aspek peningkatan kualitas, namun baru menjangkau aspek peningkatan kuantitas organisasi yang diakui pemerintah dan peningkatan frekuensi aktivitasnya saja. Aktivis gerakan buruh pun kebanyakan bukan murni berasal dari kelompok bu- 
ruh sendiri, melainkan lebih banyak didominasi oleh LSM advokasi buruh, mahasiswa dan/ataupun kelompok "demonstran profesional" yang bertindak memperjuangkan suatu kepentingan lain tersembunyi dengan mengatas-namakan kepentingan buruh. Dengan kata lain, lahirnya puluhan serikat buruh dan maraknya aksi buruh pada masa reformasi itu bukanlah merupakan bentuk ideal yang diinginkan untuk membebaskan buruh dari lilitan permasalahannya.

\section{Struktur Masalah Perburuhan di Indonesia}

Struktur permasalahan perburuhan dan upaya pemecahannya pada umumnya memiliki 2 dimensi, yaitu dimensi ekonomi dan dimensi politik. Demikian pula keadaanya di Indonesia. Masalah perburuhan di Indonesia menjadi masalah ekonomi sekaligus masalah politik. Keberadaan dimensi politik pada masalah perburuhan ini menuntut negara memecahkannya melalui kebijakan intervensi yang mengatur aktivitas ekonomi masyarakatnya. Aparatur negara bertindak sebagal aktor yang menentukan framework atau rambu-rambu aturan main seluruh aktivitas ekonomi yang berkaitan dengan buruh. Sementara itu ditinjau dari dimensi ekonomi, persoalan perburuhan dipandang sebagai masalah yang menuntut diselesaikan melalui prinsip-prinsip ekonomi. Namun efektivitas penyelesaian berdasar prinsip ekonomi tersebut senantiasa bias pada kepentingan aktor yang lebih kuat secara ekonomi. Kaum buruh yang lemah secara ekonomi pada umumnya tetap menjadi kelompok yang tertindas.

Penyelesaian masalah perburuhan yang exhaustive perlu menjangkau kedua dimensi tersebut. Jadi perlu mefibatkan aktor ekonomi dan aktor politik secara bersamaan. Penyelesaian persoalan perburuhan secara parsial, dalam arti hanya menjangkau salah satu dimensi saja tidak akan menyelesaikan persoalan empiris secara tuntas comprehensive. Penyelesaian yang hanya melibatkan aktor politik saja dalam bentuk kebijakan pemerintah - tanpa didukung pelaku ekonomi - akan menghadapi masalah pada tahap implementasinya. Cara ini tidak akan mampu menyelesaikan persoalan perburuhan ini sampai ke akarakarnya. Demikian pula sebaliknya, penyelesaian oleh aktor ekonomi saja - tanpa intervensi negara - tidak akan mampu memecahkan masalah perburuhan ini secara adil untuk semua kelompok yang berkepentingan.

Selanjutnya, aturan main yang dibuat oleh aparatur negara yang sekaligus juga merangkap sebagai pelaku ekonomi - dalam kaitan ini aparatur negara memiliki kepentingan ekonomi subyektif dan sekaligus ke- 
pentingan politik - menyebabkan aturan main tersebut tidak bisa netral, cenderung memihak pada kepentingan-kepentingan penguasa politik. Di Indonesia, disamping pemerintah banyak bertindak sebagai regulator, dalam hal-hal tertentu juga banyak bertindak sebagai pelaku bisnis. Keberadaan berbagai bentuk BUMN dan kepemilikan saham pemerintah dalam perusahaan-perusahaan swasta merupakan indikator gejala ini. Peran ganda ini menyebabkan aparatur pemerintah sulit untuk bersikap netral dalam menengahi berbagai bentuk perselisihan antara buruh dengan pengusatra. Padahal, kepentingan negara dalam kaitan ini begitu dominan dalam tiga dekade terakhir. Diantaranya adalah kepentingan pemerintah menarik dan mempertahankan investasi asing, kepentingan pemerintah meningkatkan perolehan devisa, kepentingan pemerintah meningkatkan pertumbuhan serta stabilitas ekonomi dan sebagainya. Dengan konstelasi kepentingan yang demikian inilah nasib kaum burun terus terabaikan demi kepentingan negara atau pemerintah sendiri. Aparatur negara terdorong untuk mendominasi proses pengambilan keputusan publik. Akses kaum buruh untuk ikut serta menentukan pengambilan keputusan yang menyangkut kepentingan dirinya sangat kecil, ticiak signifikan. Sejalan dengan itu buruh terus dipandang se- bagai komponen mesin produksi. Pandangan buruh sebagai manusia yang memiliki harkat martabat lebih daripada sekedar mesin produksi ditenggelamkan begitu saja oleh kepentingan-kepentingan ekonomi penguasa dan pihak-pihak yang dekat dengan penguasa. Jarak buruh terhadap forum pembuatan kebijakan pemerintah sangat jauh dari memadai. Persoalan perburuhan di Indonesia menjadi terredam dan bersifat latent. Lambat atau cepat, pada skala kecil ataupun besar, persoalan perburuhan ini terus-menerus berpotensi meledak. Para pengambil kebijakan pembangunan Indonesia di masa lalu, terutama masa pemerintahan Soeharto, ibarat telah menimbun "amunisi" persoalan perburuhan yang siap meledak sewaktu-waktu, tinggal menunggu bergeraknya faktor pelatuk saja (trigger factor).

Pemerintah di saat menjalankan kekusaannya tidak akan pernah steril dari berbagai kepentingan disekitarnya. Bahkan ia sendin memiliki kepentingan subyektif yang harus diperjuangkan di tengah sistem politik yang dibangunnya, terutama adalah kepentingan mempertahankan dan melanggengkan kekuasaannya. Seperti ditulis Mas'oed (1989 : Xv), dalam masyarakat seperti indonesia, fungsi negara dan penyelenggara urusan negara tidak hanya sekedar memproses tuntutan yang diajukan kelompok kepentingan sehingga menjadi sebuah ke- 
bijakan saja, tetapi mereka juga berusaha mencapai tujuan-tujuan mereka sendiri dan seringkali berusaha mengubah struktur turtutan yang diajukan masyarakat. Pada tingkat praksis, yaitu ketika pemerintah membutuhkan banyak dana untuk menjalankan fungsi dan mempertahankan kekuasaannya, ia cenderung aktif memilih memposisikan diri lebih dekat dengan pengusaha, karena dapat menjadi sumber penerimaan yang potensial untuk mendukung misi pemerintah di saat itu. Kebijakan-kebijakan yang dikeluarkannya cenderung memihak kepentingan pengusaha. $\mathrm{Hal}$ ini berimplikasi apabila terjadi perselisihan antara buruh dengan pengusaha, pernerintah sulit untuk bersikap netral. Kebijakankebijakan yang dikeluarkannya cenderung memihak kepentingan kaum pengusaha, baik pengusaha sebagai mitra bisnis maupun pengusaha sebagai sumber perolehan devisa negara. Manakala kebijakan pemerintah semacam itu mendapat tentangan kaum buruh, maka perilaku para pelaksana kebijakan tersebut di lapangan banyak berubah sifat menjadi sangat represif terhadap kaum buruh. Kebijakan-kebijakan perburuhan yang seperti itu ternyata terus berlanjut, seolah telah menjadi garis nasib kaum buruh di Indonesia. Pemerintahan tränsisi di bawah kepemimpinan Presiden BJ. Habibie (1998 - 1999) dan pemerintahan demokratis di bawah Presiden Abdurrahman Wahid (1999
- 2001), yang pada awalnya diharapkan mampu membawa perubahan, ternyata tidak mampu menolaknya. Bias kepentingan yang mengarah pada optimalisasi kepentingan penguasa dan mengabaikan kepentingan buruh masih tetap ada dan dominan. Adanya bias kepentingan ini ditandai lebih seringnya kaum buruh memprotes kebijakan-kebijakan pemerintah daripada protes yang dilakukan kaum pengusaha atas kebijakan yang sama. Karena seringnya kaum buruh memprotes kebijakan-kebijakan pemerintah ini, maka sering pula pemerintah melalui alat-alat kekuasaannya bertindak represif terhadap kaum buruh pada masa kekuasaan presiden-presiden tersebut.

Sebagaimana dikemukakan pada bagian awal tulisan ini, pada awal masa pemerintahan Presiden Megawati keadaan agak berubah. Penunjukkan Jacob Nuwa Wea aktivis advokasi buruh - sebagai Menteri Tenaga Kerja telah memberi angin segar dan harapan baru bagi perjuangan kepentingan buruh di Indonesia. Namun demikian upaya implementasi kebijakan-kebijakan yang dikeluarkan Menteri Tenaga Kerja tersebut hampir selalu terhenti pada tingkatan normatif saja. Pelaksanaan kebijakan tersebut di tingkat lapangan, terutama yang membutuhkan sarana dan prasarana yang harus disediakan pengusaha - biasa- 
nya berdampak pada peningkatan kesejahteraan buruh - banyak menghadapi kendala. Akhirnya bisa diduga sebelumnya, bahwa kebijakankebijakan pemerintah yang berpihak pada komunitas buruh ini tidak efektif dan tidak lebih hanya merupakan aksi politis dari pejabat pemerintah yang ingin merangkul simpati kaum buruh saja.

Berkaitan dengan rumusan kebijakan perburuhan pada masa pasca refomasi politik 1998 kiranya masih banyak kebijakan perburuhan-yang terlalu parsial dan tidak terrencana secara matang serta tidak didasarkan pada pemikiran mendalam menyangkut prediksi munculnya masalah pada tingkat implementasinya. Disamping itu tidak pula dipikirkan bagaimana pengaruhnya pada sistem ekonomipolitik yang melingkupinya, baik di tingkat nasional maupun internasional. Dengan minimnya pemikiran prospektif ke depan seperti itu maka pada tahap implementasinya muncul masalah betapa sulitnya menegakkan konsistensi hukum oleh pemerintah sendiri. Disamping itu pemerintah juga tidak cukup memiliki wibawa dan sanksi untuk memaksa perusahaanperusahaan agar melaksanakan kebijakan-kebijakan tersebut. Akhirnya muncul kebijakan-kebijakan pemerintah yang tidak bisa diimplementasikan, kebijakan-kebijakan pemerintah yang tidak konsisten, serta kebijakankebijakan pemerintah yang dilanggar oleh aparatur pemerintah sendiri. Menghadapi kebijakan-kebijakan yang tidak konsisten tersebut, kalangan pengusaha membacanya sebagai tidak adanya kepastian hukum di Indonesia. Hal-hal inilah kiranya yang masih menjadi problema yang dihadapi pemerintah-pemerintah masa pasca reformasi politik Indonesia tahun 1998 dalam membangun ekonomi Indonesia.

1 SK Menaker No. 150 Tahun 2000 ini sebenarnya sudah direvisi dengan SK Menakertrans No. 78 dan No. 111 Tahun 2001. Namun demikian, karena SK revisi itu ditentang oleh kaum buruh hingga menimbulkan aksi anarkhis besar-besaran di Bandung 13 - 14 Juli 2001 maka berdasarkan keputusan lisan Menakertrans beberapa hari setelah aksi buruh tersebut, SK Menaker No. 150 Tahun 2000 itu tetap diberlakukan.

2 Keputusan Gubernur DKI Jakarta No. 3052 Tahun 2001 tentang UMP DKI Jakarta Tahun 2002 ini digugat oleh sekelompok pengusaha yang tergabung dalam APINDO di PTUN Jakarta. Walaupun gugatan APINDO itu menang di PTUN, namun Menakertrans Jacob Nuwa Wea tetap pada pendiriannya yang melindungi kaum busuh. SK Gubernur DKI Jaya itu oleh Menakertrans dinyatakan tetap 
harus dilaksanakan semua perusahaan. Bagi perusahaan yang keberatan diharuskan menulis surat kepada pemerintah disertai dengan alasanaiasannya. Menindaklanjuti surat keberatan dari perusahaanperusahaan itu kondisi keuangan akan di-audit tim dari Depnakertrans dan kemudian akan ditentukan kebijakan selanjutnya

\section{Daftar Pustaka}

Budiardjo, Miriam (1992), Dasardasar IImu Politik., P.T. Gramedia Pustaka Utama, Jakarta.

Clark, John (1995), NGO dan Pembangunan Demokrasi., P.T. Tiara Wacana Yogyakarta.

Djumialdji, FX. (1982), Pejanjian Perburuhan., Cetakan ke 3, AlHikmah, Yogyakarta.

(1982), Pemutusan Hubungan Kerja (Perselisihan Perburuhan Perorangan).. Cetakan ke 3, Al-Hikmah, Yogyakarta.

(1982), Perselisihan Perburuhan Kolektip., Cetakan ke 3, Al-Hikmah, Yogyakarta.

Dye, Thomas R., (1978), Understanding Public Policy., New York : Pentice-Hall Inc., Engewood Cliffs.
Gaffar, Afan (2000), Politik Indonesia, Transisi Menuju Demokrasi., Pustaka Pelajar, Yogyakarta

Kuncoro, Mudrajad., (1996), Manajemen Keuangan Intermasional : Pengantar Ekonomi dan Bisnis Global, BPFE Yogyakarta.

Lindblad, J. Thomas (ed.)., (2002), Fondasi Historis Ekonomi indonesia., Diterbitkan atas kerjasama Pusat Studi Sosial Asia Tenggara UGM dengan Pustaka Pelajar, Yogyakarta

Mas'oed, Mohtar., (1989), Ekonomi dan Struktur Politik Orde Baru 1966 - 1971., LP3ES, Jakarta.

Sulistyo, Bambang (1995), Pemogokan Buruh, Sebuah Kajian Sejarah., P.T. Tiara Wacana Yogyakarta.

Sukarno, MPA. (1980), Pembaharuan Gerakan Buruh di indonesia dan Hubungan Perburuhan Pancasila., Alumni, Bandung.

Susetiawan (2000), Konflik Sosial, Kajian Sosiologis Hubungan Buruh, Perusahaan dan Negara di Indonesia., Pustáka Pelajar, Yogyakarta.

Artikel pada majalah, surat kabar, jurnal :

Chalid, Abdul., TKI llegal dan Harga Diri Kita., KOMPAS, 28 Agustus 2002, Hal. 5. 
192

Supriyadi, M. Wahid., Diplomasi TKI, Biodata Penulis

Tanggapañ atas Tulisan A. Argo Pambudi, adalah staf peMuhaimin Iskandar., KOM- ngajar di Program Studi Pendidikan PAS, 30 Agustus Administrasi Perkantoran FIS UNY. Penulis adalah lulusan dari Program S2 Jurusan Administrasi Negara FISIPOL UGM 